\title{
Drought, climate change and vegetation response in the succulent karoo, South Africa
}

\author{
M.T. Hoffman ${ }^{\text {a* }}$, P.J. Carrick ${ }^{a}$, L. Gillson ${ }^{a}$ and A.G. West ${ }^{b, c}$
}

For the winter-rainfall region of South Africa, the frequency of drought is predicted to increase over the next 100 years, with dire consequences for the vegetation of this biodiversity hotspot. We analysed historical 20th century rainfall records for six rainfall stations within the succulent karoo biome to determine if the signal of increasing drought frequency is already apparent, and whether mean annual rainfall is decreasing. We found no evidence for a decrease either in mean annual rainfall or in the incidence of drought, as measured by the Standardised Precipitation Index (SPI) over the 20th century. Evidence points to a drying trend from 1900-1950 while no significant trend in rainfall and drought was found at most stations from 1951-2000. In a second analysis we synthesised the information concerning the response of adult succulent karoo biome plants and seedlings to extended drought conditions. General findings are that responses to drought differ between species, and that longevity is an important life history trait related to drought survival. Growth form is a poor predictor of drought response across the biome. There was a range of responses to drought among adult plants of various growth forms, and among non-succulent seedlings. Leaf-succulent seedlings, however, exhibited phenomenal drought resistance, the majority surviving drought long after all the experimentally comparative non-succulent seedlings had died. Our synthesis showed that previous studies on the impact of drought on succulent karoo biome plants differ greatly in terms of their location, sampling design, measured values and plant responses. A suite of coordinated long-term field observations, experiments and models are therefore needed to assess the response of succulent karoo biome species to key drought events as they occur over time and to integrate this information into conservation planning.

Key words: biodiversity hotspot, mortality, population dynamics, recruitment, Standardised Precipitation Index

\section{Introduction}

More than $90 \%$ of South Africa is either arid or semi-arid and drought is a characteristic feature of the climate. ${ }^{1}$ Because drought has significant ecological ${ }^{2}$ and socio-economic ${ }^{3}$ impacts, investigations into its causes, consequences and mitigation have been regularly undertaken in South Africa over the last 100 years. ${ }^{4}$ Recent climate change scenarios suggest that there will be an increase in the frequency of extreme events, including drought, particularly in the winter-rainfall region of southern Africa $^{5,6}$ as a result of the predicted pole-ward retreat of rain-bearing frontal systems. ${ }^{7}$

Such predictions raise two important questions. Firstly, is there evidence in the climate record that annual rainfall has already declined and the incidence of drought has increased over

aPlant Conservation Unit, Botany Department, University of Cape Town, Private Bag X3, Rondebosch, 7701 Cape Town.

${ }^{\mathrm{b}}$ Botany Department, University of Cape Town, Private Bag X3, Rondebosch, 7701 Cape Town.

'Department of Integrative Biology, University of California, Berkeley, Berkeley, CA 94720 , U.S.A.

*Author for correspondence: timm.hoffman@uct.ac.za the last 100 years in the winter-rainfall region of South Africa? Previous analyses of the historical winter rainfall record found little evidence either for a decline in rainfall ${ }^{8}$ or an increase in drought over the 20th century. ${ }^{1}$ However, a more detailed analysis of Namaqualand's rainfall record described the pattern as spatially complex, with some areas exhibiting wetter and others drier conditions since $1950 .{ }^{7}$ Unequivocal evidence for a recent increase in drier conditions, such as was recorded for the Sahel in the 1970s and 1980s, ${ }^{9}$ will help motivate the region to prepare for the inevitable consequences of less rain and help offset some of the worst effects of drought. A detailed analysis of the historical rainfall record will also place any future drought in its proper context in terms of the intensity and duration.

The second question which arises from the climate change scenarios is concerned with the response of vegetation to drought. Both the fynbos and succulent karoo biomes, which characterise the winter-rainfall region of South Africa, are internationally recognised for their high levels of biodiversity and endemism. ${ }^{10}$ Oscillating wet and dry climatic conditions in the succulent karoo and a moderate climatic history within the succulent karoo have both been suggested to be instrumental in the development of high levels of floral diversity. ${ }^{11,12}$ The moderate climatic history argument has lead to the suggestion that the flora is vulnerable to the effects of climate change. ${ }^{12}$ What will be the impact of less rain and a higher incidence of drought on the vegetation of these biomes? While several studies explored the impact of future climate change on fynbos ${ }^{13}$ and succulent karoo biome vegetation ${ }^{12}$ none has assessed the historical impact of drought on fynbos species and only four studies have been undertaken in the succulent karoo biome. All have focused on the response of leaf- and stem-succulent shrubs relative to non-succulent evergreen and deciduous shrubs and have returned contradictory results. Some studies have reported that leaf succulents were negatively affected by drought ${ }^{14,15}$ while at other sites leaf succulents were either hardly affected at all ${ }^{16}$ or were less affected ${ }^{17}$ than non-succulent shrubs.

In the first part of this paper we examine the 20th century rainfall record at six stations across the succulent karoo biome to test whether annual rainfall has declined and whether or not the incidence of drought has increased since 1900. In the second part we review the results of previous studies to understand the impact of drought events on both adult plants and seedlings which occur within the region.

\section{Methods}

\section{Rainfall and drought}

Long-term trends in annual rainfall over the period 1900-2000 were investigated at six representative succulent karoo biome sites located at regular intervals along a north-south (Lekkersing, Springbok, Clanwilliam) and west-east (Worcester, Oudtshoorn, Steytlerville) gradient within the biome (Fig. 1). The choice of station was based on the availability of reliable long-term data, the absence of any local orographic influence and their location relative to the sites where the drought studies were undertaken. Annual rainfall values were extracted from 


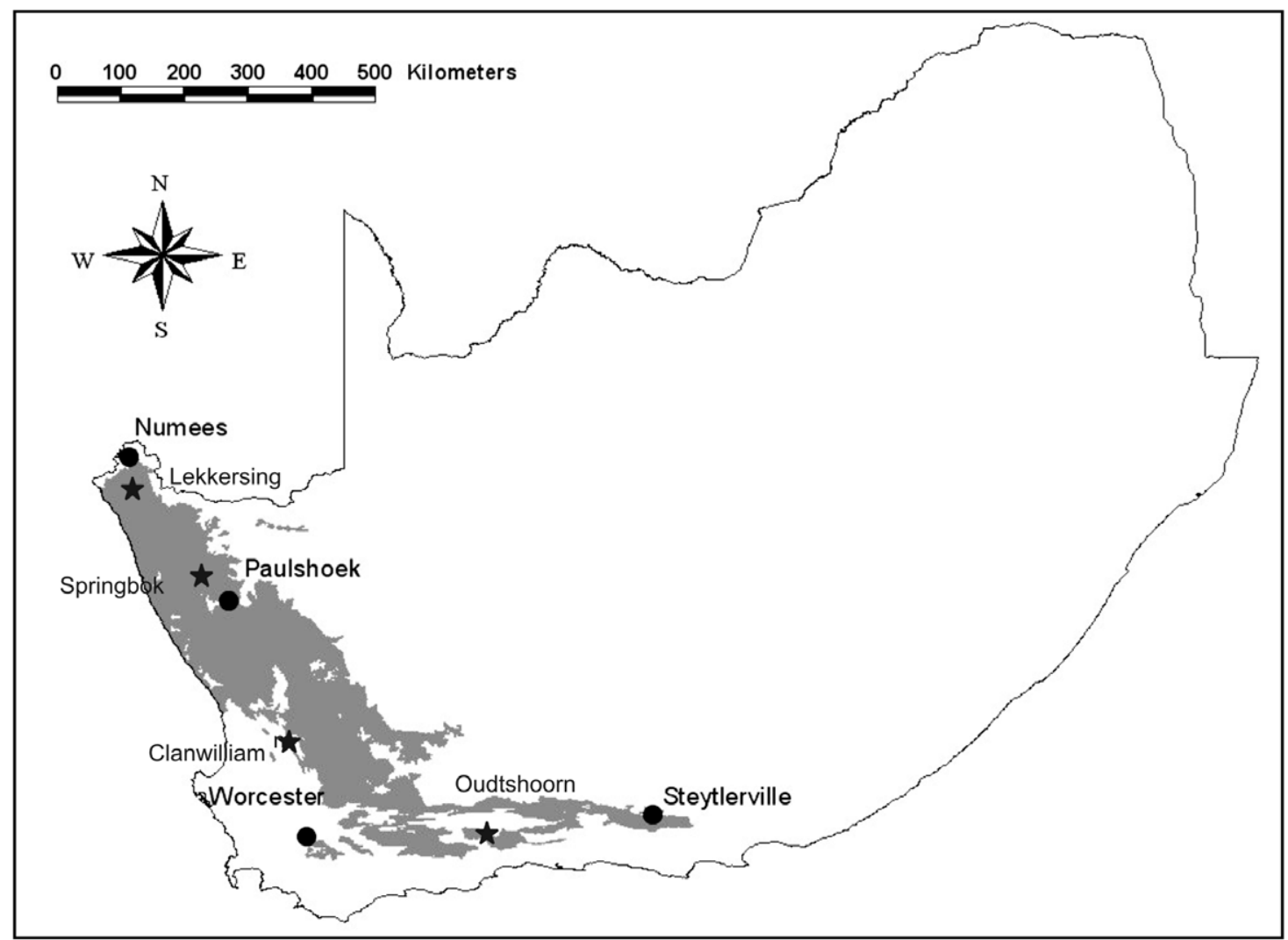

Fig. 1. Location of the four main drought studies (Numees, Paulshoek, Worcester, Steytlerville) in the succulent karoo biome and six weather stations (Lekkersing, Springbok, Clanwilliam, Worcester, Oudtshoorn, Steytlerville) used in the rainfall and drought analysis.

Lynch $^{18}$ and augmented by data from the South African Weather Service. ${ }^{19}$ A Mann-Kendall analysis for trend ${ }^{20}$ was used to test whether there had been a significant change in annual rainfall over the 20th century as well as for the periods 1900-1950 and 1951-2000 at each of the six rainfall stations. This non-parametric test for trend calculates an $S$ statistic based on the sign comparisons of pairs of values and compares them to a standard $Z$ frequency distribution. ${ }^{21}$

The same long-term rainfall record for the six stations mentioned above was used to investigate the incidence of drought over the 20th century in the succulent karoo biome. We used a Standardised Precipitation Index (SPI) ${ }^{1,22}$ for a 12-month time scale and present the SPI value for the end of the winter rainfall season (i.e. August) each year for each of the six rainfall stations. A Mann-Kendall analysis for trend in the SPI values was used to test whether there was a significant increase or decrease in the incidence of drought over the 20th century as well as for the periods 1900-1950 and 1951-2000.

\section{Vegetation response to drought}

The effect of drought on adult succulent karoo biome plants was assessed using the four main studies that have been undertaken in the region ${ }^{14-17}$ (Fig. 1). The experimental design of each study was described and the key findings summarised, with a particular focus on the effect of drought on the three dominant growth forms in the region, namely leaf succulent, stem succulent and non-succulent shrubs.

A synthesis of the three main studies ${ }^{16,23,24}$ which have investigated the effect of drought on the survival of leaf succulent and non-succulent shrub seedlings was also undertaken. Details of the experimental design of each study and the response of leaf succulent and non-succulent seedlings to an extended drought treatment were analysed.

\section{Results}

Rainfall and drought

\section{Annual rainfall}

During the 20th century, total annual rainfall fluctuated considerably at the six succulent karoo biome climate stations analysed (Fig. 2). No stations showed either a significant increase or decrease in annual rainfall over the full 100-year record from 1900-2000. When divided into pre- and post-1950 periods, Springbok $(n=50, Z=-1.66, P<0.05)$ and Worcester $(n=50$, $Z=-3.61, P<0.001)$ showed a significant downward trend in annual rainfall for the period 1900-1950. There was no significant trend in annual rainfall for the post- 1950 period for any of the climate stations, except for Lekkersing, that showed a significant increase in rainfall from 1965-2000 $(n=36, Z=2.48$, $P<0.01)$. These results were unaffected when a Bonferroni correction was applied $\left(P_{\text {crit }}=0.017\right)$, except the 1900-1950 Springbok trend, that became non-significant.

\section{Standardised Precipitation Index}

Throughout the 20th century, periods of meteorological drought, as measured by the Standardised Precipitation Index (SPI), have fluctuated with periods of high rainfall (Fig. 3). Major drought periods, which have been widespread in the winterrainfall region, occurred during the periods 1924-1925, 1927-1929, 1949, 1969-1970, 1978-1979 (although Steytlerville was not affected at this time) and 1998-1999. Widespread wet periods occurred in 1917-1918, 1921-1922, 1925, 1954-1955, 1977 and 1996-1997.

There was no significant trend in the incidence of drought over the 20th century for the stations investigated, except for Springbok, that showed a significant increase in the incidence of drought from $1900-2000(n=99, Z=-2.20, P<0.01)$. However, 

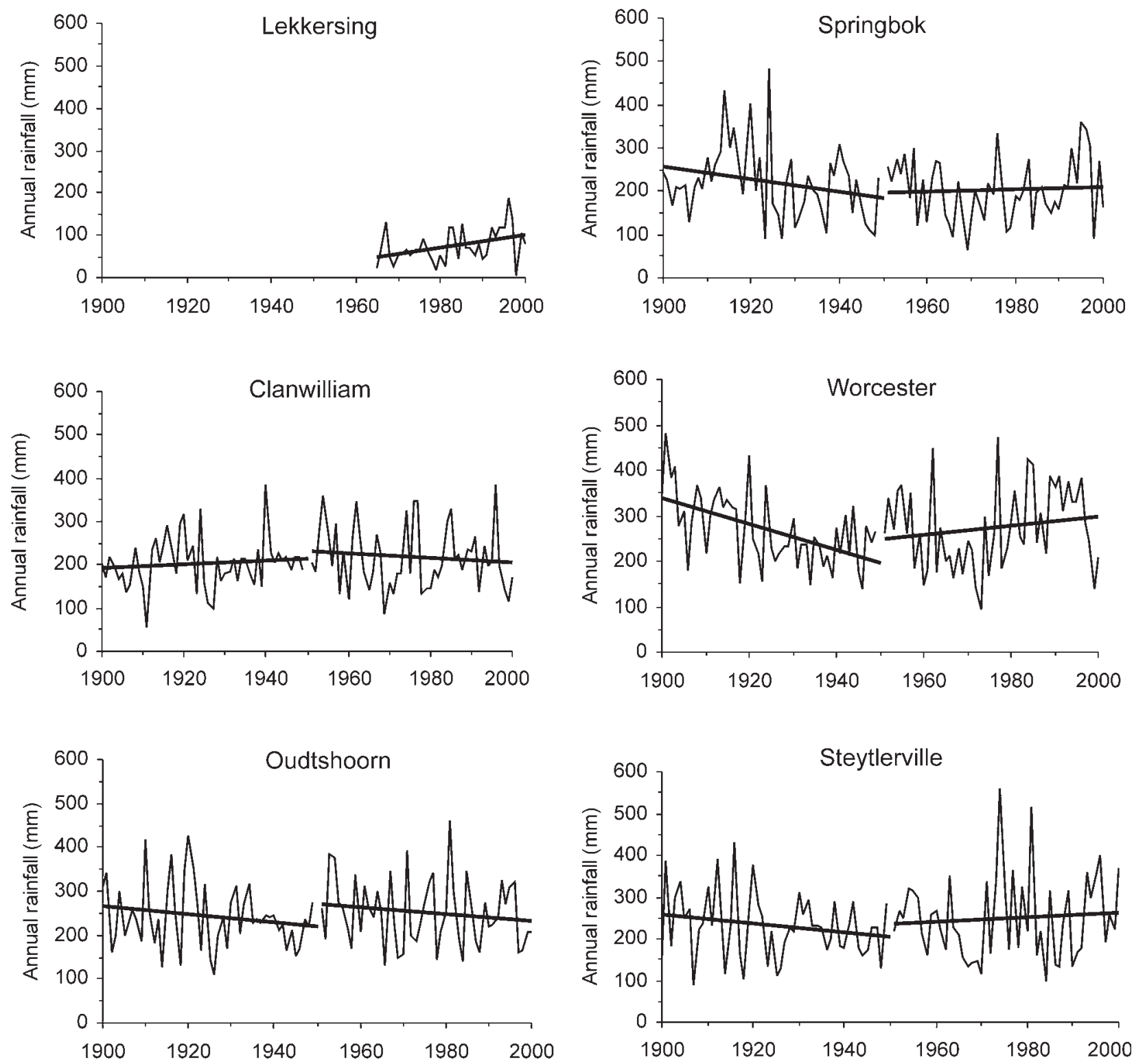

Fig. 2. Annual rainfall totals in the 20th century for six stations in the succulent karoo biome with linear trend lines shown for the periods $1901-1950$ and $1951-2000$ except for Lekkersing where the trend line is from 1965-2000.

for the period 1900-1950, Springbok $(n=49, Z=-2.66$, $P<0.001)$, Worcester $(n=49, Z=-5.03, P<0.001)$, Oudtshoorn $(n=49, Z=-2.31, P<0.01)$ and Steytlerville $(n=49, Z=-2.26$, $P<0.01)$ all showed a significant increase in the incidence of drought. In contrast, at none of the rainfall stations has the incidence of drought increased since 1951. At Lekkersing there has been a significant decrease in the incidence of drought from 1965-2000 ( $n=36, Z=2.22, P<0.01)$.

Vegetation response to drought

\section{Field studies on adult plant mortality}

A summary of the four main drought studies carried out in the succulent karoo biome is shown in Table 1 and the key rainfall and drought characteristics at each of the sites are detailed in Table 2. Midgley and van der Heyden ${ }^{15}$ used an experimental approach to investigate the impact of drought on adult plant responses while the other three studies were observations of plant mortality after the drought had been broken. The studies were widely scattered across the succulent karoo biome and differed significantly in terms of their sampling design, what was recorded, as well as their key findings.
In the southern Richtersveld at Numees (Fig. 1), the 1979/80 drought reduced both species richness and the number of individuals relative to the average values which were recorded over the next 17 years (Table 1 ). Jurgens et al. ${ }^{14}$ showed that populations of the four leaf-succulent Aizoaceae species investigated in detail, exhibited a high degree of turnover. There were significant inter-specific differences in temporal pattern which were often unrelated to prevailing rainfall conditions (i.e. dry and wet spells). Both recruitment and mortality (measured as a percentage of the observed population) were continuous over the monitoring period and ranged between $62 \%$ and $89 \%$ and between $60 \%$ and $85 \%$, respectively. The mean age of individuals of these four species ranged from 4.6 to 5.6 years.

Carrick $^{16}$ reported the mortality of the six most abundant species at Paulshoek in the eastern Kamiesberg (Fig. 1, Table 1). He found very low levels of drought-related deaths irrespective of their positions along a degradation gradient (differing largely in grazing intensity). Mortality in the two shallow-rooted leaf-succulent shrubs investigated, Leipoldtia schultzei and Ruschia robusta, was similar at 3.5\% and 3.8\%, respectively. For the stem-succulent shrub, Euphorbia decussata, mortality was 

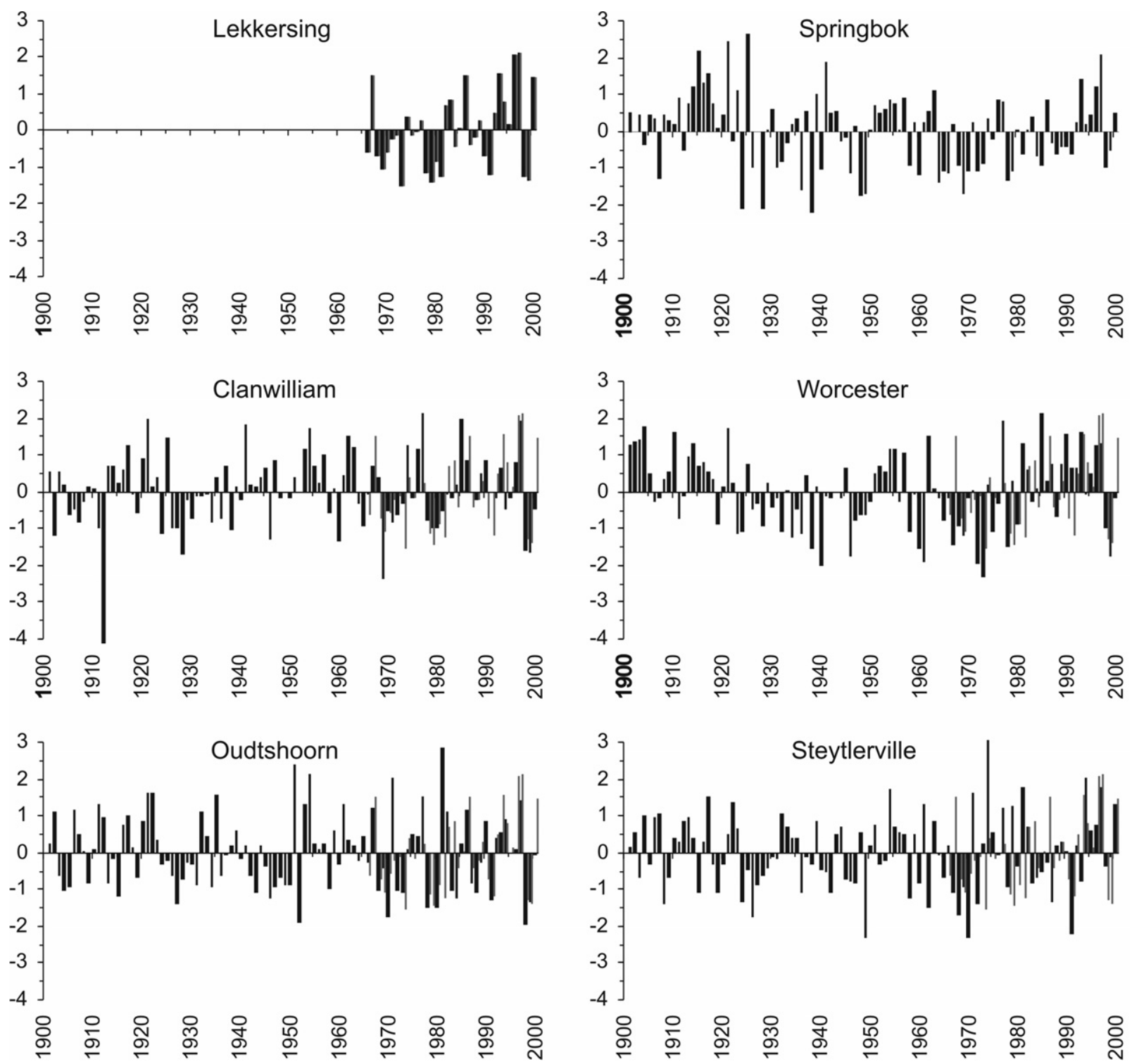

Fig. 3. Standardised Precipitation Index (SPI) values for six weather stations within the succulent karoo biome for the period 1900-2000 except Lekkersing which is from 1965-2000. SPI values are for a 12-month period from September to August (i.e. end of the rainy season) each year.

even lower at $2.0 \%$. In the three non-succulent shrubs investigated, mortality was $0.3 \%$ and $1.8 \%$ for Hirpicium alienatum and Tripteris sinuatum, respectively, although for Galenia africana it was considerably higher at $5.4 \%$. While the non-succulents are all relatively deep-rooted species, the first two mentioned above are late-successional species. G. africana, however, is usually the first shrub to colonise heavily grazed or highly disturbed, bare areas. Of the three, G. africana is relatively short-lived, ${ }^{25}$ while $H$. alienatum is likely to have the highest longevity.

In their experimental manipulation of rainfall at the Worcester Veld Reserve (Fig. 1), Midgley and van der Heyden ${ }^{15}$ reported higher levels of drought impact on leaf-succulent shrubs and less for stem-succulent and non-succulent species (Table 1). The $\mathrm{LD}_{50}$ value (i.e. the number of days of drought required to kill $50 \%$ of the shoots) for the leaf-succulent shrub, Ruschia caroli, was 259 days while for stem-succulent species, Euphorbia mauritanica and E. burmannii, the values were 343 and 595 days, respectively. For the non-succulent evergreen species, Pteronia incana, the $\mathrm{LD}_{50}$ value was 518 days. Another non-succulent, evergreen shrub, $P$. paniculata and a non-succulent, deciduous shrub, Lycium cinereum, showed minimal shoot die-back after 600 days of drought. Midgley and van der Heyden ${ }^{15}$ showed that
L. cinereum had access to ground water although this was not the case for P. paniculata.

Milton et al. ${ }^{17}$ observed a shift in growth form dominance near Steytlerville following the 1990/1 drought (Fig. 1, Table 1). Overall perennial plant cover was more than halved by the drought with a greater impact on non-succulent than succulent shrubs. The two most common non-succulent shrubs, Eriocephalus ericoides and Pentzia incana, were particularly negatively impacted by the drought, losing $88 \%$ and $70 \%$ of their canopy cover values, respectively. Population recovery in the immediate post-drought period was also slow and for the first two years after 1991 the vegetation was co-dominated by perennial succulent shrubs and by a suite of post-drought pioneers, including the alien pauciennial, Atriplex lindleyi.

Of the three locations where observations of drought impacts were carried out, Numees near Lekkersing in the Richtersveld is clearly the most arid site with the highest variability in annual rainfall (Table 2). The 1979/80 drought was also the most extreme of all the sites for nearly all of the values computed from the daily rainfall record. The Paulshoek study site in the Kamiesberg and the one at Baroe near Steytlerville are more similar in terms of mean annual rainfall and most drought parameters. However, 
Table 1. Summary of key drought studies undertaken in the succulent karoo biome.

\begin{tabular}{|c|c|c|c|}
\hline Authors & Location and study site description & Sampling design and measurement & Main findings \\
\hline Jürgens et al. ${ }^{14}$ & $\begin{array}{l}\text { Numees, southern Richtersveld. } \\
\text { Very steep, south-facing slope on } \\
\text { shallow, rocky quartzite. }\end{array}$ & $\begin{array}{l}\text { One } 10 \times 10 \mathrm{~m} \text { plot in which the number of indi- } \\
\text { vidual perennial species was mapped over } 17 \\
\text { years after the } 1979 / 80 \text { drought and included a } \\
\text { detailed analysis of the population dynamics of } \\
\text { four leaf-succulent shrubs. }\end{array}$ & $\begin{array}{l}\text { Drought impact reduced species richness and } \\
\text { the number of individuals to about } 60 \% \text { of the } \\
\text { mean value recorded for the next } 17 \text { years. The } \\
\text { four leaf-succulent shrubs exhibited species- } \\
\text { specific patterns of continuous and high levels of } \\
\text { recruitment and mortality. Mean age was } 4.9 \\
\text { years. }\end{array}$ \\
\hline Carrick $^{16}$ & $\begin{array}{l}\text { Paulshoek, eastern Kamiesberg. } \\
\text { Plains on relatively deep, gneiss- } \\
\text { derived loamy sands. }\end{array}$ & $\begin{array}{l}\text { Sixty } 5 \times 5 \mathrm{~m} \text { plots located along a grazing } \\
\text { intensity gradient in which individuals of six } \\
\text { species were classified as either alive or as } \\
\text { having died in the } 1998 / 99 \text { drought. }\end{array}$ & $\begin{array}{l}\text { Drought-induced mortality was relatively low } \\
\text { (leaf succulents }=3.7 \% \text { of the individuals died in } \\
\text { response to the drought, stem succulents }=2.0 \% \\
\text { and non-succulents }=2.5 \% \text { ) }\end{array}$ \\
\hline $\begin{array}{l}\text { Midgley and } \\
\text { van der Heyden }{ }^{15}\end{array}$ & $\begin{array}{l}\text { Worcester Veld Reserve. Steep, } \\
\text { south-facing slope on shallow, } \\
\text { shale-derived soils. }\end{array}$ & $\begin{array}{l}\text { Two } 6 \times 6 \mathrm{~m} \text { rain exclosures in which the } L D_{50} \\
\text { (i.e. number of days to } 50 \% \text { shoot mortality) of } \\
\text { select perennial shrubs was recorded. }\end{array}$ & $\begin{array}{l}\text { Leaf-succulent shrubs appeared more drought } \\
\text { sensitive than stem-succulent and non-succu- } \\
\text { lent shrubs. Two of the four non-succulent } \\
\text { species showed minimal dieback despite nearly } \\
600 \text { days without rain. }\end{array}$ \\
\hline Milton et al. ${ }^{17}$ & $\begin{array}{l}\text { Baroe, near Steytlerville. Valleys, } \\
\text { plains and slopes with a wide range } \\
\text { of soil types, depths and degree of } \\
\text { rockiness. }\end{array}$ & $\begin{array}{l}\text { Seven } 20 \mathrm{~m} \text { line transects within valleys, plains } \\
\text { and slopes along which the canopy cover of pe- } \\
\text { rennial shrubs was classified as either live, } \\
\text { moribund or dead after the 1990/91 drought. }\end{array}$ & $\begin{array}{l}\text { Pre-drought cover for non-succulents }(23 \%) \text { and } \\
\text { succulents }(20 \%) \text { was similar. Drought reduced } \\
\text { perennial cover from } 45 \% \text { to } 21 \% \text {. Mortality for } \\
\text { non-succulents was higher }(65 \%) \text { than for suc- } \\
\text { culents }(42 \%) \text {, resulting in a succulent-domi- } \\
\text { nated perennial flora following drought. }\end{array}$ \\
\hline
\end{tabular}

the drought at Steytlerville appears more severe largely because of the overall longer period of drought (nearly $50 \%$ longer than at Paulshoek) and the greater number of days without a rainfall event $>5 \mathrm{~mm}$. In addition, the conditions preceding the drought period itself differed considerably between the sites. The Steytlerville and Richtersveld droughts were preceded by average or below-average rainfall for five years (Fig. 3). In contrast, the Kamiesberg drought was preceded by five years of above-average rainfall.

\section{Greenhouse studies on seedling mortality}

Three experiments have tested the impact of drought on the survival of succulent and non-succulent shrub seedlings (see Table 3). All studies were carried out under greenhouse conditions using seedlings grown in pots. The experiments differ in terms of their sampling design, soil medium used, length of the experimental drought period and time taken to reach permanent wilting point. There are also no shared species, although in all experiments the leaf-succulent shrubs investigated were species within the genus Ruschia (Aizoaceae). Despite these differences, all investigations showed that the seedlings of leaf succulents were able to survive long periods without water even when soil water content dropped close to $0 \%$ of field capacity. For non-succulent shrubs, however, there was considerable variation in their ability to withstand drought. In some species (e.g. Galenia africana ${ }^{16}$, and the two fynbos species used by Lechmere-Oertel and Cowling ${ }^{24}$ ) death occurred within a month of the start of the drought treatment. For Pteronia pallens and Tripteris sinuatum ${ }^{23}$ however, survival of at least some individuals was nearly six times as long, with the last individuals dying 125 and 160 days, respectively, after watering had stopped.

\section{Discussion}

\section{Rainfall and drought}

Future climate change scenarios suggest that over the next 100 years the winter-rainfall region, including the succulent karoo biome, will experience hotter and drier conditions than those experienced in the 20th century ${ }^{26}$ although there may be considerable spatial variation. ${ }^{7}$ These changes may have dire consequences for the region's biodiversity. ${ }^{12}$ Our review addressed two main questions: Is there evidence in the historical rainfall record

Table 2. Comparative information about the meteorological drought events at each of the three study sites where observations on the effects of natural drought on succulent karoo biome plants have been carried out . Meteorological drought was defined, using the Standardised Precipitation Index (SPI) for a 12-month time scale, as the period during which the SPI is continuously negative and reaches a value of -1.0 or less. Drought conditions start when the SPI first falls below zero and ends when the $\mathrm{SPI}$ is greater than zero following a value of -1.0 or less. ${ }^{22}$

\begin{tabular}{|c|c|c|c|}
\hline & \multicolumn{3}{|c|}{ Study site location } \\
\hline & Richtersveld & Kamiesberg & Steytlerville \\
\hline \multicolumn{4}{|l|}{ Study site characterisation } \\
\hline Author(s) of study & Jürgens et al. ${ }^{14}$ & Carrick $^{16}$ & Milton et al. ${ }^{17}$ \\
\hline Closest weather station & Lekkersing & Springbok & Steytlerville \\
\hline Distance to study site $(\mathrm{km})$ & 50 & 90 & 25 \\
\hline Period of rainfall record & 1965-2000 & 1900-2000 & 1900-2000 \\
\hline Mean annual rainfall (mm) & 75 & 213 & 240 \\
\hline Coefficient of variation (\%) & 52 & 37 & 37 \\
\hline \multicolumn{4}{|l|}{ Drought characterisation } \\
\hline Period of meteorological drought & Apr 1978-May 1982 & Jun 1998-Aug 1999 & Oct 1990-Jul 1992 \\
\hline No. of months of drought & 50 & 15 & 22 \\
\hline Longest period without rain (days) & 149 & 64 & 74 \\
\hline Longest period without rain event $>5 \mathrm{~mm}$ (days) & 341 & 137 & 232 \\
\hline
\end{tabular}


Table 3. Summary of three separate seedling experiments that measure the ability of succulent karoo and arid fynbos species to survive drought. All three experiments use field-collected seed, establish the seedlings in pots under greenhouse conditions and then measure the mortality of individual species following the cessation of all watering. In all three experiments the mortality of leaf-succulent species is compared with that of non-succulent species.

\begin{tabular}{|c|c|c|c|}
\hline Authors & Experimental design & Soil medium & Main findings \\
\hline Esler and Phillips ${ }^{23}$ & $\begin{array}{l}\text { Three species and } 50-120 \text { seedlings per } \\
\text { species in pots sown at densities of } 10,6 \text { or } 1 \\
\text { seedling per pot depending on the species } \\
\text { and not watered for } 400 \text { days. Soil water po- } \\
\text { tential fell below permanent wilting point ( } 1.5 \\
\text { MPa) after } 35-140 \text { days. }\end{array}$ & $\begin{array}{l}2 \text { parts soil from Prince Albert, } 4 \text { parts } \\
\text { pasteurised river sand and } 1 \text { part com- } \\
\text { post. }\end{array}$ & $\begin{array}{l}70 \% \text { of the seedlings of the succulent shrub, } \\
\text { Ruschia spinosa, survived the experiment } \\
\text { while none of the two non-succulent shrubs, } \\
\text { Pteronia pallens and Tripteris sinuatum } \\
\text { survived. Seedlings of the latter two species } \\
\text { were all dead within } 125 \text { and } 160 \text { days, } \\
\text { respectively. }\end{array}$ \\
\hline $\begin{array}{l}\text { Lechmere-Oertel } \\
\text { and Cowling }\end{array}$ & $\begin{array}{l}\text { Four species and } 9-20 \text { seedlings per } \\
\text { species, each in their own pot and not } \\
\text { watered for } 77 \text { days. Soil water potential was } \\
\text { not measured. }\end{array}$ & $\begin{array}{l}\text { Separate experiments on shale and } \\
\text { sandstone soils collected from the } \\
\text { Matjiesrivier Nature Reserve. }\end{array}$ & $\begin{array}{l}100 \% \text { of the seedlings of the two succulent } \\
\text { shrubs investigated, Ruschia spp., survived } \\
\text { on sandstone soils and } 80 \% \text { survived on the } \\
\text { shale soils. None of the non-succulent } \\
\text { shrub seedlings, Passerina vulgaris and } \\
\text { Leudadendron pubescens, survived the } \\
\text { experiment on either of the soils. The mean } \\
\text { survival period for these two species was } 26 \\
\text { days on sandstone and } 22 \text { days on shale. }\end{array}$ \\
\hline Carrick $^{16}$ & $\begin{array}{l}\text { Two species and } 35 \text { seedlings per species, } \\
\text { each in their own pot and not watered for } 160 \\
\text { days. Soil water potential, in all pots, fell } \\
\text { below permanent wilting point ( } 1.5 \mathrm{MPa}) \\
\text { after } 6 \text { days. }\end{array}$ & $\begin{array}{l}1 \text { part soil from Paulshoek (eastern } \\
\text { Kamiesberg) and } 1 \text { part acid-washed } \\
\text { river sand. }\end{array}$ & $\begin{array}{l}86 \% \text { of the seedlings of the succulent shrub, } \\
\text { Ruschia robusta, survived the experiment } \\
\text { while all of the seedlings of the non-succulent } \\
\text { shrub, Galenia africana, were dead within } 21 \\
\text { days. }\end{array}$ \\
\hline
\end{tabular}

that a drying trend has already started? How have plants within the succulent karoo biome responded to drought in the past?

Our analysis finds no evidence for a decreasing trend in annual rainfall from 1900-2000 for the six rainfall stations investigated, and except for Springbok, there was no increase in the incidence of drought over the 20th century. Our analysis is in agreement with Warburton and Schulze ${ }^{8}$ who also report no decrease in annual rainfall for the winter-rainfall region in the latter part of 20 th century. In fact, they suggest that relative to the period 1950-1969, the winter-rainfall region experienced an increase in rainfall from 1980-1999. MacKellar et al.'s analysis ${ }^{7}$ of Namaqualand's historical rainfall record suggests a spatially variable pattern with annual rainfall totals at some stations (e.g. Springbok) showing a decrease in rainfall while locations to the north (e.g. Lekkersing) and south (e.g. Kamieskroon) have experienced the opposite trend. Springbok experienced exceptionally high rainfall during the period 1911-1925 with total annual rainfall nearly $50 \%$ higher for these 14 years relative to the mean value for the next 75 years. These 14 wet years are the main driver behind the pattern of a significantly increased incidence of drought at this location over the 20th century.

What emerges strongly from our study is that most stations in the succulent karoo biome showed a significantly higher incidence of drought between 1900 and 1950 relative to the second half of the 20th century. Coupled with the high stocking rates that built up steadily during the first half of the 20th century, ${ }^{27}$ the impact of episodic, severe drought (e.g. in 1949) on the vegetation of the region must have been significant over this period, since drought and heavy grazing combine to reduce plant cover, especially of palatable species. ${ }^{28,29}$

Concern over drought in southern Africa is not new. There were severe droughts in southern Africa in 1821-23, 1845-7, and 1862-63, which triggered the emergence of a 'desiccationist' narrative, linking decreasing rainfall with human activities, especially the removal of vegetation and reflecting international concern over climate change and conservation at global, regional and local scales. ${ }^{30}$

Similarly, despite the lack of evidence of increasing drought from the rainfall records, a desiccationist narrative has emerged around the effects of climate change on the succulent karoo biome. ${ }^{12}$ Concerns for the diversity and stability of natural resources in a drier, hotter succulent karoo are based on future scenarios derived from General Circulation Models (GCMs), rather than evidence of increasing drought from historical sources. When historical analyses have been conducted they show either little change in the long-term record, ${ }^{31}$ a spatially complex trend in the data ${ }^{7}$ or an increasing trend in rainfall in the latter part of the 20th century (ref. 8; this study). It might still be the case that rainfall in the succulent karoo biome will decline in the 21st century as suggested by most GCMs. ${ }^{5,6}$ However, an analysis of the historical record has failed to support such a generalised desiccationist narrative for the 20th century in the winter-rainfall region.

\section{Vegetation responses}

Despite the succulent karoo biome's unique flora and ecology and relatively poor conservation status, to date, only four studies have examined the effects of drought in this region. These four studies were conducted at widely different locations within the biome, each with its own particular on-site land use and climate history, and drought characteristics, and using a wide diversity of approaches. Under such circumstances, finding coherent patterns of drought sensitivity amongst growth forms would be indicative of very strong selective pressures on those growth forms in response to drought. Perhaps unsurprisingly, no such pattern emerged from the four case studies, indicating instead, a heterogeneous system where the specific flora and drought conditions resulted in different patterns of mortality.

All four studies summarised in this analysis suggest that some succulent karoo biome species are more susceptible to the impact of drought than others but provide contradictory results concerning the impact of drought on different growth forms. Except for the short-lived, leaf-succulent species within the family Aizoaceae in the Richtersveld study ${ }^{14}$ and Pentzia incana, Eriocephalus ericoides at Steytlerville ${ }^{17}$ and to some extent Galenia africana at Paulshoek, ${ }^{16}$ all the other species were remarkably resistant to drought, irrespective of growth form. Lycium cinereum, Pteronia paniculata and Hirpicium alienatum stand out as being particularly drought resistant. 
Our analysis provided little evidence for the suggestion that adult succulent plants are more susceptible to drought than non-succulents. ${ }^{15}$ While data from the Richtersveld ${ }^{14}$ and Worcester ${ }^{15}$ suggest that leaf succulents are susceptible to drought, the majority of species reported on in these two case studies are short-lived, relatively weedy leaf-succulent species colonising disturbed environments. In Steytlerville, leafsucculent species survived the drought better than non-succulent shrubs ${ }^{17}$ while in the Kamiesberg, there was little difference in survivorship between leaf-, stem- and most non-succulent shrubs. ${ }^{16}$ A more definitive answer about the relative drought sensitivity of succulents and non-succulent growth forms awaits additional research which directly addresses this issue. Clearly, the growth form classes are too broad to accommodate the wide diversity of life history traits exhibited by the species that define them. A far narrower differentiation of growth forms based on traits such as longevity, size at maturity and population density is needed. ${ }^{32}$ Carrick, ${ }^{16}$ for example, suggests that the lifespan of a species is a far better predictor of its ability to survive a drought than its broad growth form definition.

Of particular interest was the variation in mortality between the different case studies. Most comparable in terms of climate are the Paulshoek ${ }^{16}$ and Steytlerville ${ }^{17}$ studies. Both of these locations have a similar mean annual rainfall and the drought characteristics appeared to be similar in length and severity (Table 2). However, the vegetation responses differed considerably. Carrick ${ }^{16}$ recorded percentage mortality of less than $5 \%$, whereas Milton et al. ${ }^{17}$ report up to $65 \%$ mortality rates. What could account for this variation in mortality? It is possible that conditions prior to the onset of the drought affected drought susceptibility. In Steytlerville, total annual rainfall was well below the long-term average for half of the six years prior to the 1990 drought. In contrast, the Paulshoek drought was preceded by five years of very high rainfall. The causes of drought mortality in plants are remarkably poorly understood, but it is possible that the cumulative stress of several years of below-average rainfall may result in higher rates of mortality. ${ }^{33}$

While few generalisations can be made about the impact of drought on adult plants within the succulent karoo biome, the seedlings of leaf-succulent Ruschia spp. exhibited a remarkable ability to survive extreme drought conditions. The three seedling experiments suggest that there might be a coherent pattern of drought resistance among the Aizoaceae or possibly the leaf-succulent growth form, which would indicate a response to strong selective pressures. This phenomenon needs to be tested for other leaf-succulent genera not only within the Aizoaceae but also within other succulent families common in the region, such as Crassulaceae. The measurement of soil water potential is critical in experiments of this nature and field-based observations of the fate of individual seedlings over time ${ }^{34}$ would also be helpful.

This work was supported in part by the project BIOTA Southern Africa which is sponsored by the German Federal Ministry of Education and Research under promotion number $01 \mathrm{LC}$ 0024A and the EU-funded project WADE (Contract No. 506680). The Mazda Wildlife Vehicle Fund kindly supplied a courtesy vehicle.

Received 3 June 2008. Accepted 4 February 2009.

1. Rouault M. and Richard Y. (2003). Intensity and spatial extension of drought in South Africa at different time scales. Water SA 29,489-500.

2. Von Willert D.J., Werger M.J.A., Brinckmann E., Ihlenfeldt H.D. and Eller B.M. (1992). Life Strategies of Succulents in Deserts: With Special Reference to the Namib Desert. Cambridge University Press, Cambridge.

3. Hatch G.P. and Stafford-Smith D.M. (1997). The bioeconomic implications of various drought management strategies for a communal herd in the semi-arid savanna of KwaZulu-Natal. Afr. J. Range For. Sci. 14, 17-25.

4. Vogel C. (1994). (Mis)management of droughts in South Africa: past, present and future. S. Afr. J. Sci. 90, 4-6.
5. Hewitson B., Tadross M. and Jack C. (2005). Scenarios from the University of Cape Town. In Climate change and water resources in southern Africa: studies on scenarios, impacts, vulnerabilities and adaptation, ed. R.E. Schulze, pp. 39-56. WRC Report 1430/1/05. Water Research Commission, Pretoria.

6. Midgley G.F., Chapman R.A., Hewitson B., Johnston P., De Wit M., Ziervogel G., Mukheibir P., Van Niekerk L., Tadross M., Van Wilgen B.W., Kgope B., Morant P.D., Theron A., Scholes R.J. and Forsyth G.G. (2005). A status quo, vulnerability and adaptation assessment of the physical and socio-economic effects of climate change in the Western Cape. ENV-S-C 2005-073. p. 170. CSIR Environmentek, Stellenbosch.

7. Mackellar N.C.,Hewitson B.C. and Tadross M.A. (2007). Namaqualand's climate: recent historical changes and future scenarios. J. Arid Environ. 70, 604-614.

8. Warburton M. and Schulze R.E. (2005). Historical precipitation trends over southern Africa: a hydrology perspective. In Climate change and water resources in southern Africa: studies on scenarios, impacts, vulnerabilities and adaptation, ed. R.E. Schulze, pp. 325-338. Water Research Commission, Pretoria.

9. Anyamba A. and Tucker C.J. (2005). Analysis of Sahelian vegetation dynamics using NOAA-AVHRR NDVI data from 1981-2003. J. Arid Environ. 63, 596-614.

10. Myers N., Mittermeier R.A., Mittermeier C.G., Da Fonseca G.A.B. and Kent J. (2000). Biodiversity hotspots for conservation priorities. Nature 403, 853-858.

11. Midgely G.F., Hannah L., Roberts R., Macdonald D.J. and Allsopp J. (2001) Have Pleistocene climate cycles influenced species richness patterns in the greater Cape Mediterranean Region? J. Med. Ecol. 2, 137-144.

12. Midgley G.F. and Thuiller W. (2007). Potential vulnerability of Namaqualand plant diversity to anthropogenic climate change. J. Arid Environ. 70, 615-628.

13. Bomhard B., Richardson D.M., Donaldson I.S., Hughes G.O., Midgley G.F Raimondo D.C., Rebelo A.G., Rouget M. and Thuiller W. (2005). Potential impacts of future land use and climate change on the Red List status of the Proteaceae in the Cape Floristic Region, South Africa. Global Change Biol. 11, 1452-1468.

14. Jürgens N., Gotzmann I.H. and Cowling R.M. (1999). Remarkable medium-term dynamics of leaf succulent Mesembryanthemaceae shrubs in the winter-rainfall desert of northwestern Namaqualand, South Africa. Plant Ecol. 142, 87-96.

15. Midgley G.F. and Van Der Heyden F. (1999). Form and function in perennial plants. In The Karoo: Ecological Patterns and Processes, eds. W.R.J. Dean and S.J. Milton, pp. 91-106. Cambridge University Press, Cambridge.

16. Carrick P. (2001). Shrub community dynamics in a South African semi-desert. Ph.D. thesis, University of Cambridge, Cambridge.

17. Milton S.J., Dean W.R.J., Marincowitz C.P. and Kerley G.I.H. (1995). Effects of the 1990/91 drought on rangeland in the Steytlerville Karoo. S. Afr. J. Sci. 91, 78-84.

18. Lynch S.D. (2003). Development of a raster database of annual, monthly and daily rainfall for southern Africa. WRC Report No. 1156/1/03. Water Research Commission, Pretoria.

19. South African Weather Service. Online at: www.weathersa.co.za

20. Salmi T., Määttä A., Anttila P., Ruoho-Airola T. and Amnell T. (2002) Makesens 1.0. Mann-Kendall test and Sen's slope estimates for the trend of annual data. Version 1.0 Freeware. Finnish Meteorological Institute, Helsinki. Online at: www.fmi.fi/ organization/contacts_25.html

21. Modarres R. and Da Silva V.D.R. (2007). Rainfall trends in arid and semi-arid regions of Iran. J. Arid Environ. 70, 344-355.

22. McKee T.B., Doesken N.J. and Kleist J. (1993). The relationship of drought frequency and duration of time scales. In Eighth Conference on Applied Climatology, American Meteorological Society, pp. 179-186. Anaheim, California.

23. Esler K.J. and Phillips N. (1994). Experimental effects of water-stress on semiarid karoo seedlings: implications for field seedling survivorship. J. Arid Environ. 26, 325-337.

24. Lechmere-Oertel R.G. and Cowling R.M. (2001). Abiotic determinants of the fynbos/succulent karoo boundary, South Africa. J. Veg. Sci. 12, 75-80.

25. Wiegand T., Milton S.J., Esler K.J. and Midgley G.F. (2000). Live fast, die young: estimating size-age relations and mortality pattern of shrubs species in the semi-arid Karoo, South Africa. Plant Ecol. 150, 115-131.

26. Midgley G.F., Rutherford M.C. and Bond W.J. (2001). The Heat is On... Impacts of Climate Change on Plant Diversity in South Africa. National Botanical Institute, Cape Town.

27. Hoffman M.T. and Rohde R.F. (2007). From pastoralism to tourism: the historical impact of changing land use practices in Namaqualand. J. Arid Environ. 70, 641-658.

28. Hein L. (2006). The impacts of grazing and rainfall variability on the dynamics of a Sahelian rangeland. J. Arid Environ. 64, 488-504.

29. Watson I.W., Westoby M. and Holm A.M. (1997). Demography of two shrub species from an arid grazed ecosystem in Western Australia 1983-93. J. Ecol. 85, 815-832.

30. Grove R. (1989). Scottish missionaries, evangelical discourses and the origins of conservation thinking in southern Africa, 1820-1900. J. S. Afr. Studies 15, $163-187$.

31. Kelso C. and Vogel C. (2007). The climate of Namaqualand in the nineteenth century. Clim. Change 83, 357-380.

32. Goldberg D.E. and Turner R.M. (1986). Vegetation change and plant demography in permanent plots in the Sonoran Desert. Ecology 67, 695-712.

33. Mcdowell N., Pockman W.T., Allen C.D., Breshears D.D., Cobb N., Kolb T., Plaut J., Sperry J., West A.G., Williams D.G. and Yepez E.A. (2008). Mechanisms of plant survival and mortality during drought: why do some plants survive while others succumb to drought? New Phytol. 178, 719-739.

34. Bowers J.E. and Turner R.M. (2002). The influence of climatic variability on local population dynamics of Cercidium microphyllum (foothill paloverde). Oecologia 130, 105-113. 